\title{
RESEARCH PAPER \\ Metaphorical Use of Animals in English and Punjabi Exocentric Compounds: A Cognitive-Cultural Perspective
}

\author{
Saima Jamshaid*1 Prof. Dr. Raja Nasim Akhtar ${ }^{2}$
}

1. Ph. D Scholar, English, Foundation University Rawalpindi Campus, Punjab, Pakistan

2. Dean, Faculty of Arts, Foundation University Rawalpindi, , Punjab, Pakistan

\begin{tabular}{|c|c|}
\hline DOI & $5484 /$ pssr.2022(6-I)10 \\
\hline ER INFO & RACT \\
\hline $\begin{array}{l}\text { d: } \\
15,2021 \\
\text { d: } \\
15,2022 \\
20,2022\end{array}$ & $\begin{array}{l}\text { The study examines the } \\
\text { and Punjabi exocentric } \\
\text { such as idioms and prov } \\
\text { but no attention is paid } t \\
\text { in exocentric compounds }\end{array}$ \\
\hline $\begin{array}{l}\text { Keywords: } \\
\text { Animal } \\
\text { Metaphors, } \\
\text { Cultural } \\
\text { Conceptualization } \\
\text { English and } \\
\text { Punjabi, } \\
\text { Exocentric } \\
\text { Compounds, } \\
\text { Metonymic } \\
\text { Relations }\end{array}$ & $\begin{array}{l}\text { light that due to the cultural variations there are certain } \\
\text { similarities and disparities in the negative and positive } \\
\text { conceptualization and metaphorical use of animals in the } \\
\text { languages. The study argues every exocentric compound is } \\
\text { culture specific and its meaning cannot easily arrived at by } \\
\text { simple cognition. The study further argues that every constituent } \\
\text { in an exocentric compound carries some cultural specific } \\
\text { conceptualizations and there are certain culturally determined } \\
\text { metonymic relations. Thus, for arriving at the metaphorical }\end{array}$ \\
\hline $\begin{array}{l}\text { *Corresponding } \\
\text { Author }\end{array}$ & $\begin{array}{l}\text { role. The data comprised of } 50 \text { English and Punjabi exocentric } \\
\text { compounds and was analyzed with the combo of cognitive and } \\
\text { cultural linguistics framework. The analysis showed that due to } \\
\text { cultural differences there are some similarities and disparities in } \\
\text { the conceptualizations of animals. The culturally determined } \\
\text { metonymic relations help in the formation and for arriving at the } \\
\text { metaphorical meanings. }\end{array}$ \\
\hline
\end{tabular}

\section{Introduction}

Since Aristotle to present day metaphors carry an important place in the research field. In the literature for more than 2000 years metaphors are taken as fundamental figure of speech. From the 1980's conceptual metaphors and metonymies have grasped the attention of the linguists from cultural and cognitive linguistics. The most influential work by Lakoff and Jhonson (1980) revolutionized the concepts of metaphor and metonymy. They gave the idea that metaphor and 
metonymy are not the rhetoric devices as previously believed, these play an important role in shaping people's thought and behavior. Later, in late 1990 and 2000 scholars (e.g., Panther and Radden, 1999 and Barcelona, 2000), added a lot in the field. The linguists (e.g., Barcelona, 2003; Lakoff, 1987, 1993; Lakoff \& Johnson, 1980) define metaphor as mapping between source domains to a target domain by means of conceptualizations. It means a thing or entity from a source domain is understood in a target domain with reference to another entity or element. On the other hand, metonymy means mapping of an entity on to another entity with in the single domain (Barcelona, 2000/2003)

For the last three decades metaphors have been used as a figure of thought instead of language ornaments. The use of specific in various concepts and their source domains have been the area of research in different languages. The metaphoric domains include food, time, clothing, birds and animals etc. In different languages, e.g., English, Spanish, Hungarian etc., the animal metaphors have been examined by linguists and researchers (e.g., Thornton, 1999; Rodríguez, 2009; Kleparski 2002; Wang \& Dowker 2008; Kiełtyka \& Kleparski, 2009 and Estaji \& Nakhavali, 2011). However, there has been scarcely any contrastive analysis of metaphors in exocentric compounds in English and Punjabi.

The study examines animal metaphors in English and Punjabi exocentric compounds. The study focuses on describing the similarities and disparities in the positive and negative conceptualization of different animals in two different asymmetrical languages. Furthermore, the study describes how the animals are used as one of the constituents in the formation of an exocentric compound and for the metaphorical representation of a humanbeing. The study also highlights the metonymic relations found between the constituents of the compounds. Thus, to achieve the said goals the study with the combo of cognitive and cultural linguistics provides a comparative/contrastive semantic analysis of animal metaphors in two asymmetrical languages and highlights the idea how the meaning is arrived at in exocentric compounds.

\section{Literature Review}

Lakoff and Johnson (2003, p. 36) state that the primary function of metonymy is understanding one thing in terms in terms of another thing. Metonymy not only performs the referential functions but also helps us in understanding one entity in terms of another. In the PART FOR WHOLE metonymy many parts may stand for a whole. It is to up to our understanding that the part which is selected refers to which aspect of the whole. For example if we say that we need some more hands to complete the work. Here hands stand for people. The point to be noted is that using part (hand) to stand for whole (person) makes no sense. We need to pick out a particular characteristic of the people, i.e., hardworking, which is associated with the hands. 
The only difference between metaphor and metonymy is predicative and referential use of the terms (p. 36). Ruiz de Mendoza (1999, p.1) distinguishes two types of interaction patterns between metaphor and metonymy. The first distinction is where the source for metonymy is provided by the metaphorical output mapping and in the second metonymic mapping helps in providing the source for metaphor. Thus, it can be concluded that with the help of metaphorical expansion of metonymy the metaphorical mapping can be constructed.

Lakoff and Turner (1989) present a different metaphorical schema. With the help of this schema the animals can be conceived. The metaphorical schemas can be constructed and the attributes and behavior of humanbeing are easily understood by comparing and contrasting with the animals.

Language is the byproduct of our personal and shared experiences of the world, the way we perceive and conceptualize it. Thus, it can be said that after having interaction with the outer world and other humanbeing in a culture we get the experiences which help in constituting our conceptual system. So by mapping the properties of one domain onto another most of the abstract concepts are understood through other concrete or simple ones. Our cultural background knowledge and conceptualizations help a lot in concrete realization of the abstract concepts.

In sociolinguistics, cognitive linguistic and cultural linguistics etc., the relationship between language and culture has always been a debating issue. The distinctions between the various groups of people is done through culture (Hofstede, 1994, p. 5). Every culture has its own specifications and conceptualizations that work as the memory banks and are the result of negotiation and renegotiation among the speech community (Langacker, 1999).

Cultural linguistics a new discipline tires to present the relationship between language and culture along with the cultural conceptualizations (Palmer 1996 \& Sharifian, 2011, 2017). Every culture has its own conceptualizations for feelings, emotions and rituals. With the help of these conceptualizations the people can easily use the things metaphorically.

\section{Material and Methods}

The study is qualitative and the data is collected manually. For the English data the internet sources (word spy) and Oxford dictionary were consulted while the Punjabi data was selected from the Wadi Punjabi Lugat. The data was presented involving animals (pet and wild) as one of the constituents in exocentric compounds. The study with the combo of cognitive and cultural linguistics tried to prove that with the help of cultural background knowledge the animals are used metaphorically for presenting human beings. The culturally determined conceptualizations help a 
lot in arriving at the metaphorical interpretation as the exocentric compounds are social phenomena and used for the sensationalization of the language. Approximately 50 exocentric compounds having animals (donkey, lion, sheep, dog, and snake) as one of the constituents were extracted from English and Punjabi dictionaries. The data was presented in tabular form with compounds and their metaphorical meanings. The Punjabi data was also presented in the glossed form too. The data was analyzed qualitatively with the combo of cognitive-cultural linguistics.

\section{Data Analysis}

The analysis revealed various types of metaphorical meanings, images related to the behavior and characteristics associated with animals in the exocentric compounds in the two languages. In the study the similarities and the disparities in the metaphorical use of animal to refer to human beings are discussed.

1. Metaphorical use of Lion in English and Punjabi Exocentric Compounds

Results and Discussion

Table. 1 (a)

English Data

\begin{tabular}{llc}
\hline S\# & Compound & Metaphorical Meaning \\
\hline 1. & Lion heart & 'A brave person' \\
\hline 2. & Lion dance & 'A traditional Chinese dance in which the performers dress \\
up like lions'
\end{tabular}

Table. 1 (b)

Punjabi Data

\begin{tabular}{ccc}
\hline S\# & Compound & Metaphorical Meaning \\
\hline 1. & $\begin{array}{c}\text { Sher dil } \\
\text { 'lion heart' }\end{array}$ & 'A brave person' \\
\hline 2. & $\begin{array}{c}\text { Sher abbi } \\
\text { 'lion water' }\end{array}$ & 'Alligator' \\
\hline 3. & $\begin{array}{c}\text { Sher vangg } \\
\text { 'lion like' }\end{array}$ & 'Muscular like a lion' \\
\hline 4. & $\begin{array}{c}\text { Sher bakri } \\
\text { 'lion goat' }\end{array}$ & 'A game of boys' and girls' \\
\hline 5. & $\begin{array}{c}\text { Sher bacha } \\
\text { 'lion cub' }\end{array}$
\end{tabular}


In English society lion is considered to be the symbol of bravery and courage. Lion is the king of all the beasts. The animal has been praised and worshipped since the ancient time. Lions are very precious animals and cannot be combined with any other animal as it is brave, dangerous and furious animal. The Western people admire the huge and muscular body of the animal and call it the king of the animals. As per the Collins English Dictionary the lion is defined as a person who is powerful and strong and other people respect or feel fear of him. In the Western culture lion is the national emblem. There are lots of exocentric compounds where the animal is used as a constituent to form compounds, a few examples are given in table 4.2 (a). In the compound sher dil 'lion heart' the animal is associated with a positive connotation for example a very brave and courageous person is always called 'lion heart'. There are many folktales about the bravery of the lion such 'Lion the jungle king' and 'The brave lion' etc.

Likewise, in Punjabi the lion carries a positive connotation. It is a symbol of bravery and courage. In Punjabi culture a brave a courageous person is always metaphorically called sher dil 'lion heart'.

Here again the question is how the compound is formed and why the person is called sher dil 'lion heart'? Looking at the metonymic relations there is a relation, i.e., ATTRIBUTE + CONTAINER. Universally, lion carries the attributes of bravery, courage etc. all these are abstract feelings and universally it is acknowledged that all these feelings are found in heart, so heart works as a CONTAINER. Thus the compound lion heart is formed. The answer to the second part of the question is there are some similarities in the attributes of the animal 'lion' and the brave person. One of the shared attribute is being daring and brave. Thus, this similarity in the attributes help not only to form the compound but also to arrive at the metaphorical meaning. Again the conceptual metaphor PEOPLE ARE LIONS seems at work here and the metaphorical use of the compound is based on the universally and culturally and shared knowledge of the speech community about the animal and the body part along with the traits of a brave person.

2. Metaphorical use of donkey in English and Punjabi Exocentric Compounds:

Table. 2 (a)

English Data

\begin{tabular}{ccc}
\hline S\# & Compound & Metaphorical Meaning \\
\hline 1. & Donkey mind & 'A stupid person' \\
\hline 2. & Donkey lick & 'Defeat resoundingly' \\
\hline 3. & Donkey year & 'Long time' \\
\hline 4. & Donkey jacket & 'A very thick jacket worn by building \\
workers'
\end{tabular}




\begin{tabular}{ccc}
\hline 5. & Donkey engine & 'A small auxiliary engine' \\
\hline & Donkey work & 'The boring or laborious part of a job' \\
\hline
\end{tabular}

Table. 2 (b): Punjabi Data

\begin{tabular}{clc}
\hline S\# & Compound & Metaphorical Meaning \\
\hline 1. & $\begin{array}{l}\text { Khota magaz } \\
\text { 'donkey mind' }\end{array}$ & 'A stupid person' \\
\hline 2. & $\begin{array}{l}\text { Khoti chaa } \\
\text { donkey walk' }\end{array}$ & 'Slow walk', \\
\hline 3. & $\begin{array}{l}\text { Khota khurki } \\
\text { donkey itching' }\end{array}$ & 'Mischiefs' \\
\hline 4. & $\begin{array}{l}\text { Khota kunn } \\
\text { donkey ear' }\end{array}$ & 'A man with long ears' \\
\hline 5. & $\begin{array}{l}\text { Khot puna } \\
\text { 'donkey doing' }\end{array}$
\end{tabular}

In English exocentric compounds, donkey is used negatively. It connotes stupidity and ignorance. For example, the compound donkey mind is used to refer to 'a stupid person'. In this compound, donkey symbolizes stupidity. Thus, in the English society the characteristic of the donkey to that of negative traits, i.e., stupidity are ascribed as reference to people's personality. The conceptual metaphor PEOPLE ARE ANIMAL can easily be identified in the compound donkey mind.

In Punjabi exocentric compound, for example khota magaz 'donkey mind', a donkey is regarded as a stupid animal and is used to illustrate the ability of the human mind. In both English and Punjabi donkey is famous for its stupid and foolish attributes. On the other hand, a person who does foolish acts is called fool or stupid. Such a person is metaphorically called khota magaz 'donkey mind'. Now the question is why the person is called khota magaz? To get the answer to the question first let us have a look on the culturally determined role of constituents taking part in the formation of compound and the semantic relation between them and the person the compound refers to. The compound is the combination of two constituents carrying certain characteristics and take part in arriving at the metaphorical meaning. The first constituent khota 'donkey' is an animal which carries certain attributes like stupidity, foolishness etc. The second constituent magaz 'mind' is a body part, the producer and the store house of all the thoughts. All sort of thoughts are kept in it, so it works like a container. Thus, the semantic relation ATTRIBUTE+CONTAINER plays its role in the formation of the compound khota magaz is formed. Now let us move towards the main question how the compound is metaphorically used to represent a stupid person? As discussed above that the animal donkey and the person carry certain culturally conceptualized attributes. One of the attributes, i.e., stupidity is found common in both which help in arriving at the metaphorical interpretation. This 
metaphorical interpretation is based on the culturally shared knowledge about the traits and characteristics of the constituents and the behavioral attitude of the stupid person. Thus, it can be said that the culturally shared knowledge plays an important role in the formation and the metaphorical interpretation of the exocentric compounds.

3. Metaphorical use of dog in English and Punjabi Exocentric Compounds:

Table. 3 (a)

English Data

\begin{tabular}{ccc}
\hline S\# & Compound & Metaphorical Meaning \\
\hline 1. & Dog/Puppy fat & $\begin{array}{c}\text { 'The fat on the body of a child that vanishes } \\
\text { away as s/he grows up' }\end{array}$ \\
\hline 2. & Dog box & 'A cap shaped like the mouth of a lion' \\
\hline 3. & Dog eared & 'A book with turned corners of the pages' \\
\hline 4. & Dog disease & 'Viral flu' \\
\hline 5. & Dog biscuit & 'A special biscuit for dogs' \\
\hline
\end{tabular}

Table. 3 (b)

Punjabi Data

\begin{tabular}{ccc}
\hline S\# & Compound & Metaphorical Meaning \\
\hline 1. & $\begin{array}{c}\text { Kuttae lok } \\
\text { 'dog people' }\end{array}$ & 'Very bad people' \\
\hline 2. & $\begin{array}{c}\text { Kutta khung } \\
\text { 'dog cough' }\end{array}$ & 'Whooping cough' \\
\hline 3. & $\begin{array}{c}\text { Kutti zabaan } \\
\text { 'dog tongue' }\end{array}$ & 'Foul language' \\
\hline 4. & $\begin{array}{c}\text { Kutta mootiaa } \\
\text { 'dog urinate' }\end{array}$ & 'Fungus' \\
\hline 5. & $\begin{array}{c}\text { Kutta kaa } \\
\text { 'dog grass' }\end{array}$ & 'A herb that sticks with legs like a dog' \\
\hline
\end{tabular}

In English society, the positive values such as obedience, faithfulness and loyalty are associated with dogs. In the lives of English people dog carries an important place. The animal is kept as a pet at homes and is loved more than even the children. Dogs are kept as pets as well as for the purpose of hunting. Thus, owing a dog is a source of pride for English. There are certain compounds having dog as one of the constituents. Puppy fat 'the fat on the body of a child that vanishes away as $\mathrm{s} /$ he grows up' is an example. In this compound the child is conceptualized as a puppy. The conceptual metaphor CHILDREN ARE PUPPIES seems at work here. The metonymic relation between the constituents is CHARACTERISTIC FOR ENTITY. The puppy has certain characteristics such as fatness, pulpiness and 
shedding off the pulpiness. The compound is based on the knowledge about the behavior of puppies who are pulpy and fat in their childhood but loose the fat as they grow up. On the basis of similarities in the characteristic of a small fat child and the puppy the compound is metaphorically used in a positive connotation.

Contrastively in Punjabi, expressions associated with dog metaphors tend to have negative meanings. In Punjabi culture kutta 'dog' is considered to be inferior and filthy animal. Majority of the people do not like to keep them and if in any case they do, they keep them out of the house. These are kept to guard the animals, houses or farms etc. Dog is associated with the negative and derogatory sense for example the compound kuttae lok 'very bad people'. In the compound kuttae lok 'dog people' the PEOPLE ARE DOGS conceptual metaphor is visible. This metaphor is based on the similarities in the attributes of the animal and the human being. The bad people are regarded as dogs due their un-changeable and bad behavior. Thus, most of the compounds related to dog carry a negative connotation. The metonymic relation is CHARACTERISTICS FOR ENTITY and the metaphorical meaning of the compound is derogatory. The similarity in the attributes of the dog and the human being, i.e., being bad helps in the formation and arriving at the metaphorical meaning of the compound. This metaphorical interpretation is based on the cultural conceptualizations about the animal and the bad people. Thus, it can be said that culture plays an important role in our understanding of the world as well as making the language sensationalizing.

4. Sheep metaphors in English and Punjabi Exocentric Compound

Table. 4 (a)

English Data

\begin{tabular}{ccc}
\hline S\# & Compound & Metaphorical Meaning \\
\hline 1. & Sheep head & 'Stupid person' \\
\hline 2. & Black sheep & 'Someone who brings shame to a family.' \\
\hline 3. & Vegetable sheep & 'A type of daisy' \\
\hline 4. & Sheep dog & 'A dog that cares for the sheep' \\
\hline 5. & Sheep bot & 'Nostril fly' \\
\hline
\end{tabular}

Table. 4 (b)

Punjabi Data

\begin{tabular}{ccc}
\hline S\# & Compound & Metaphorical Meaning \\
\hline 1. & $\begin{array}{c}\text { Peid chaal } \\
\text { Sheep walk' }\end{array}$ & 'Mob mentality' \\
\hline 2. & $\begin{array}{c}\text { Lisi peid } \\
\text { 'Lazy sheep' } \\
\text { Peid khaal } \\
\text { 'Sheep skin' }\end{array}$ & 'Lazy person' \\
\hline 3. & 'A coat made of sheep skin' \\
\hline
\end{tabular}




\begin{tabular}{ccc}
\hline 4. & $\begin{array}{c}\text { Peid lela } \\
\text { 'Sheep lamb' }\end{array}$ & 'An innocent person' \\
\hline 5. & $\begin{array}{c}\text { Mesi peid } \\
\text { 'Cunning sheep' }\end{array}$ & 'A cunning person' \\
\hline
\end{tabular}

In English community sheep is commonly reared for its meat, milk and fur. The animal is often associated with negativity in English, such as the compound black sheep. Here the characteristic of the sheep, i.e., appearance is mapped onto the characteristic of a person, which is bad. The semantic relation between the constituents is ATTRIBUTE+ENTITY.

Like English in Punjabi the negative meaning associated with peid 'sheep' is manifested in the compound peid chaal 'mob mentality'. The compound refers to a group of people who are easily influenced by negative things. The sheep live together in herds, thus the behavioral characteristic of a sheep's herd that stay together in the herd is mapped onto the behavioral character of people who are gullible and prone to act undesirably.

Here again the meaning is derived from the behavioral characteristic of the sheep, i.e., to follow one another undesirably. The metonymic relation is ATTRIBUTE+ENTITY. Thus the characteristic of following others undesirably of the sheep is mapped onto the characteristics of the gullible people. As per the conceptual metaphor PEOPLE ARE SHEEP the compound is used in a derogatory sense. This metaphorical conceptualization is the result of the culturally determined role played by the constituents and the knowledge about the behavioral attitude of the human beings.

5. Metaphorical use of snake in English and Punjabi Exocentric Compounds:

Table. 5 (a)

English Data

\begin{tabular}{ccc}
\hline S\# & Compound & Metaphorical Meaning \\
\hline 1. & Snake bird & 'A small fast-moving North-American freshwater fish' \\
\hline 2. & Snake dance & $\begin{array}{c}\text { 'A ritual dance of the North American Hoi Indians } \\
\text { involving the handling of live rattlesnakes }\end{array}$ \\
\hline 3. & Snake board & $\begin{array}{c}\text { 'A type of skateboard consisting of two footplates joined } \\
\text { by a bar, allowing for greater speed and maneuverability } \\
\text { than with a standard skateboard' }\end{array}$ \\
\hline 4. & Snake eyes & 'A complete lack of success' \\
\hline 5. & Snake head & 'A smuggler' \\
\hline
\end{tabular}


Table. 5 (b)

Punjabi Data

\begin{tabular}{|c|c|c|}
\hline S\# & Compound & Metaphorical Meaning \\
\hline 1. & $\begin{array}{l}\text { Sap/Naag putar } \\
\text { 'Snake son' }\end{array}$ & 'A dangerous person' \\
\hline 2. & $\begin{array}{l}\text { Naag boti } \\
\text { 'Snake herb' }\end{array}$ & $\begin{array}{c}\text { 'A type of herb used to make medicines for } \\
\text { snake bite' }\end{array}$ \\
\hline 3. & $\begin{array}{l}\text { Naag mankaa } \\
\text { 'Snake bead' }\end{array}$ & $\begin{array}{l}\text { 'A bead found in the head of a snake and is } \\
\text { used to suck the poison of a snake' }\end{array}$ \\
\hline 4. & $\begin{array}{c}\text { Naag veel } \\
\text { 'Snake creeping } \\
\text { plant' }\end{array}$ & $\begin{array}{l}\text { 'A creeping plant under which the snakes } \\
\text { live' }\end{array}$ \\
\hline 5. & $\begin{array}{c}\text { Naag chatri } \\
\text { 'Snake umbrella' }\end{array}$ & 'Mushroom' \\
\hline
\end{tabular}

Like the sheep the snake is also used in the formation of different compounds. Following the same line of analysis the compound snake head' a smuggler, especially a Chinese person who helps people in getting them to other countries illegally'. Again the conceptual metaphor PEOPLE ARE SNAKES is found in the compound. The compound is the combination of two constituents, i.e., an animal snake and a body part head.

Here the head stands for a person and the profile determinant. In the compound the conceptual metaphor is also found as the qualities of a snake having small almond shaped eyes and the secretive movements. As detecting the quite movements of a snake is hard, same is the case with a smuggler whose activities and movements are hard to be traced by the official control. The meaning of the compound is arrived at with the help of our folk knowledge about the snake as it is also considered to be a treacherous and non-trustworthy animal. The crafty and cunning people are considered snakes. The metonymic relation is ATTRIBUTE+CONTAINER

In Punjabi culture too the snake carries a negative connotation and is considered an enemy. The compound sap putar 'snake son' is an example of such type. As the snake is dangerous likewise, its babies are also dangerous. This characteristic of the snake is mapped to the behavioral attitude of a dangerous person, who always be ready to harm others. The metonymic relation ATTRIBUTE FOR ENTITY can easily be arrived at in the compound. Thus, the compound is metaphorically used for a dangerous person. This conceptualization is based on the culturally shared knowledge about the behavioral attitude of the snake and a dangerous person. 


\section{Discussion}

The data analysis illustrated some similarities and disparities in the conceptualization of the animals in both English and Punjabi exocentric compounds. The cultural and geographical differences of both English and Punjabi are the main reason of the differences in conceptualization. This is the reason that it becomes difficult for a non-native speaker to arrive at the metaphorical interpretation of exocentric compounds. For arriving at the metaphorical interpretation of any exocentric compound the cultural back ground knowledge and higher cognitive abilities play a key. Every constituent helping in the formation of any compound has its specific role and conceptualization based on the personal and the shared experiences of that speech community. Thus, the lack of knowledge about the conceptualization of the constituents poses a challenge for the non-native speakers as in the case of English and Punjabi two asymmetrical languages. Furthermore, the similarities in traits and characteristics also play an important role in the formation and metaphorical usage and interpretation of the exocentric compounds. The data analysis illustrates that some of the animals carry the same connotation in both the languages while some carry different meaning due to universal and cultural specific knowledge. Thus, for understanding the metaphorical expressions appropriately higher cognitive abilities and the cultural knowledge both are required. This is due to the differences between the abstract and the literal meanings. For arriving at the meaning form the meaning of the constituents taking part in the compound formation.

\section{Conclusion}

The study illustrated that metaphors are an important part of our life and help us to structure our thoughts and understanding the world. The ethnic cultures are represented via metaphors. The exocentric compounds are always culture specific and are metaphorical in nature. The animal exocentric compounds are not only an important part of language but are an indispensable element of culture. The comparison of two asymmetrical languages shows the cultural similarities and disparities in the conceptualization of the animals. In English and Punjabi the metaphorical meanings of different animals are great achievements. The knowledge about this phenomenon may help to improve communication and also resolve the issue of linguistic barriers in teaching a foreign language.

The universal and cultural conceptual system can easily be arrived at with the help of negative and derogatory use of animals in the exocentric compounds found in two asymmetrical languages. The Similarities and disparities in the conceptualization of the same animal and the different animal metaphors reflect cultural-specificity. This conceptualization of the animals is based on the personal and shared experiential nature of the speech community. With the help of this shared 
knowledge animals are used metaphorically. The study also shed light how the images of animals are constructed and how the metaphorical meaning is arrived at with the help of cultural knowledge. The study also proposed that for understanding the respective images of animals in two languages, i.e., English and Punjabi it is very compulsory to learn the culture of both the languages. This cultural knowledge not only helps the learners to grasp the meaning of unfamiliar expressions but also in enhancing their language acquisition. 


\section{References}

Aristotle. (1954). Rhetoric and Poetics. New York: The Modern Library.

Barcelona, A. (2000). Metaphor and Metonymy at the Crossroads (pp. 109-32). De Gruyter Mouton.

Barcelona, A. (2003). Metonymy in cognitive linguistics. Motivation in language: Studies in honor of Günter Radden, 223-255.

Estaji, A., \& Nakhavali, F. (2011). Semantic Derogation in Persian Animal Proverbs. Theory \& Practice in Language Studies, 1(9). 1213-1217.

Fontecha, A. F., \& Catalan, R. M. J. (2003). Semantic derogation in animal metaphor: a contrastive-cognitive analysis of two male/female examples in English and Spanish. Journal of pragmatics, 35(5), 771-797.

Hofstede, G. (1994). Management scientists are human. Management science, 40(1), 413.

Ho-Abdullah, I. (2011). A cognitive semantics analysis of Malay proverbs related to the dog (Canis Familiaris). Journal of Language Studies, 11(1), 125-141.

Irshad, A.P. (1999). Wadi Punjabi Lughat (2nded.). Lahore: Punjabi Adabi Board.

Kiełtyka, R., \& Kleparski, G. A. (2007). On the Indo-European nature of non-IndoEuropean animal metaphor: The case of Chinese zoosemy. Studia Anglica Resoviensia, 4(47), 88-99.

Kleparski, G. A. (2002). Lusta, mint a disznó: A hunt for 'correlative' zoosemy in Hungarian and English. Studia Anglica Resoviensia, 1(2002), 9-32.

Lakoff, G. (1987). Image metaphors. Metaphor and Symbol, 2(3), 219-222.

Lakoff, G., \& Johnson, M. (1980). Conceptual metaphor in everyday language. The journal of Philosophy, 77(8), 453-486.

Lakoff, G., \& Johnson, M. (1980). The metaphorical structure of the human conceptual system. Cognitive science, 4(2), 195-208.

Lakoff, G. (1993). The contemporary theory of metaphor. Cambridge: Cambridge University Press.

Lakoff, G \& Johnson. (2003). Metaphors We Live By. Chicago: University of Chicago Press. 
Lakoff, G., \& Turner, M. (2009). More than cool reason: A field guide to poetic metaphor. University of Chicago press.

Palmer, G. B. (1996). Toward a theory of cultural linguistics. University of Texas Press.

Panther, K. U., \& Radden, G. (Eds.). (1999). Metonymy in language and thought (Vol.4). John Benjamins Publishing Company.

Rodríguez, I. L. (2009). Of women, bitches, chickens and vixens: Animal metaphors for women in English and Spanish. Culture, Language and Representation, 7, 77-100.

Ruiz de Mendoza, Francisco, (1999). An International Journal for Interdisciplinary Studies, Tomasz Komendzinski (ed.), Institute of Philosophy, Nicolaus Copernicus University; Torun, Poland .Related Works.

Saeed, John I. (1997). Semantics. Oxford: Blackwell.

Sharifian, F. (2011). Cultural conceptualizations and language. Amsterdam: John Benjamins Publishing Company.

Sharifian, F. (Ed.). (2017). Advances in cultural linguistics. Singapore: Springer.

Thornton, P. H. (1999). The sociology of entrepreneurship. Annual review of sociology, 25(1), 1946.

Wang, C., \& Dowker, A. (2008). Interpretation of animal metaphors: Evidence from Chinese and English children and adults. Paper presented at Child Language Seminar, University of Reading. 